\title{
The Relationship of Principal Supervision, Achievement Motivation, and Job Satisfaction to Teacher Performance
}

\author{
Salikurnima *, Muhammad Saleh, Karyono Ibnu Ahmad \\ Master Program of Education Management, Universitas Lambung Mangkurat, Banjarmasin 70123, Indone- \\ sia
}

Article history:

Submission October 2020

Revised January 2021

Accepted January 2021

${ }^{*}$ Corresponding author:

E-mail: nima.minda@gmail.com

\begin{abstract}
This study aims to determine the relationship of principal school supervision (X1), achievement motivation (X2), and job satisfaction (Z) to teacher performance (Y) in SMPN (Public Junior High School) in Dusun Timur Subdistrict, East Barito Regency. This study used a quantitative descriptive method, with a total sample of 91 teachers. The data collection technique used observation and questionnaire distribution. The researcher used multiple correlations and path diagrams to show the relationship between variables according to the assumptions to analyze the data. The calculation and analysis results indicate all statistical hypotheses, where $>$ at the $5 \%$ significance level. The study results show that there is a very small sign and a positive effect on the relationship between variables. Suggestions: School principals' supervision should be more planned and done regularly, at least once every semester. Schools need to give awards to teachers who have achievement motivation and high teaching performance. Teachers' perception regarding principal supervision is defined as the teacher's control in teaching and learning activities. It needs to increase motivation to get more achievement in all fields.
\end{abstract}

Keywords: Principal supervision, achievement motivation, job satisfaction, teacher performance

\section{Introduction}

Teachers are the spearhead of an educational organization at the school level. This is since teachers' quality will affect the quality of implementation and education results in schools (Bakar, 2018; Gherasim et al., 2012). Educational organizations in schools always need to be developed, not just as a learning platform for students to face changes in the era of uncertainty in modern life recently (Schratz \& Schle, 2014; Walker \& Vogt, 1987). Characteristics needed in an educational organization today must observe the demands for change both internally and externally to align itself in meeting society's needs along with the times. Teacher duty will face various problems. Therefore, teachers must create and maintain conditions for the teaching and learning process that are conducive, comfortable, and safe optimally. Besides, one thing that needs to be considered to achieve high teacher performance is motivation from teachers to improve their performance as a whole (Tastan et al., 2018; Blaskova et al., 2015).

Based on the preliminary observations at several public junior high schools in Dusun Timur Sub-district, East Barito Regency in February 2020, it shows that teachers' performance is still felt not satisfying. In everyday reality, there are still facts, among others: The making of teaching and learning framework is not optimal, even last year's instruments only change the writing of the year; the lack of teacher willingness to create varied learning; low ability to conduct and utilize classroom action research; there are still few students who pay attention to the explanation/ lecture by the teacher, so they do not absorb the lessons learned, and 
some students have not achieved satisfying score. Besides, one thing that is often becoming a problem in the current learning process is to activate students to be involved in the teaching and learning process (Hubackova, 2015; Lile \& Kelemen, 2014).

Considering these facts, a teacher should understand the components of teacher work assessment by supervision in measuring the level of performance. These components are used as control tools to achieve teacher performance satisfaction, including; quality of work, work speed, work skills, initiative in working, workability, and ways of communicating (Kelimeda et al., 2018).

The Job satisfaction of SMPN teachers in the Dusun Timur Subdistrict is not yet optimal. The temporary conclusion is seen from teacher discipline in school attendance. According to the preliminary observations, it can be seen that some teachers will attend or be at school when there is teaching time or come when the lesson time is approaching. The rest, if there are no teaching hours, they prefer not to go to teach but do other things that generate economic value. One of the reasons often used is the distance between home and workplace.

Motivation is the driving force within a person to do an activity or job, manifested in the form of concrete actions (Yunus et al., 2011; Poernamawijaya et al., 2018). When teachers have high work motivation, they will be motivated and improve their ability to plan, implement, and evaluate the school's applicable curriculum to get maximum work results (Lourmpas \& Dakopoulou, 2014; Bentea \& Anghelache, 2012). The work motivation of SMPN teachers in the Dusun Timur Subdistrict is not optimal yet. The temporary conclusion is seen from teacher discipline in utilizing the significant time of the learning process. According to the preliminary observations, it can be seen that some SMPN teachers work only to fulfill obligations, not responsibility. This situation indicates that a teacher's motivation needs to be supported by tools that lead to the need to increase achievement to affect the teacher's performance, which is qualified (Claudia, 2015; Kandemira \& Gür, 2009; Luskova \& Hudakova,
206). Another influencing factor is work pattern, which supports each other among fellow teachers and other school members (Bush \& Grothjohann, 2020; Liu \& Tsai, 2017; Vangrieken et al., 2015).

This can be realized through the activity of principal supervision. Supervision is a form of management implementation in teacher personnel training in the educational environment (Behroozi et al., 2014; Veloo et al., 2013). Permendiknas No.13 (2007) regarding Principal Standards have supervisory functions with the following competencies: a) Planning an academic supervision program to improve teacher professionalism; b) Conducting academic supervision to teachers by using the appropriate supervision approach and technique; c) Following up on the results of academic supervision to the teacher to improve teacher professionalism.

However, the implementation of supervision is still varied so that the results achieved from the supervision activities carried out by the principals on the teachers are not as expected. The problem that occurs in the field is some of the school principals have never supervised in the class so that they do not give maximum direction to teachers, especially the teachers who still have many shortcomings. Besides, the principal does not supervise his busy schedule, including meetings and activities outside of school.

Based on the explanation above, the researchers feel that teachers still face too many problems working well. Indeed, this is because of many factors that influence the principal's role as a supervisor, teacher achievement motivation, and teacher's job satisfaction. The objectives of this study are: (1) Describing principal supervision, achievement motivation, job satisfaction, and teacher performance; (2) Analyzing the relationship between principal supervision and teacher job satisfaction; (3) Analyzing the relationship between achievement motivation and teacher performance satisfaction; (4) Analyzing the relationship between principal supervision and teacher performance; (5) Analyzing the relationship between achievement motivation and teacher performance; (6) Analyzing the relationship between 
job satisfaction and teacher performance; (7) Analyzing the relationship between principal supervision and job satisfaction with teacher performance; (8) Analyzing the relationship between achievement motivation and performance satisfaction with SMPN teachers' performance in Dusun Timur Subdistrict, East Barito Regency.

\section{Material and Methods}

The method used was the descriptive method with the correlation technique. The correlation technique is a study that describes the relationship between two or more variables (Fraenkel et al., 2012). This study used four variables, referred to knowing the relationship between the principal supervision variable (X1), achievement motivation variable (X2), job satisfaction variable (Z) as the independent variable, and teacher performance variable $(\mathrm{Y})$ as the dependent variable. The relationship between the variables in this study is described in Figure 1 below.

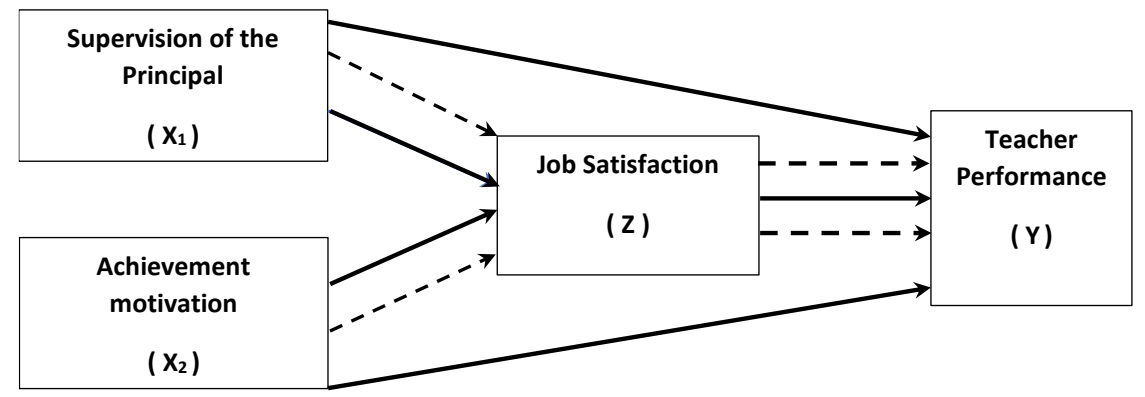

Figure 1. Research paradigm

\section{Population and sample}

In this study, the population in Table 1 was the teachers who have a minimum work period of 5 years with undergraduate education (S1), which amounted to 117 people.

Table 1. The population of SMPN teacher

\begin{tabular}{lc}
\hline Calculation of SMPN population and samples & $\begin{array}{c}\text { The population of SMPN } \\
\text { teachers (people) }\end{array}$ \\
\hline SMPN 1 Tamiang Layang & 36 \\
SMPN 2 Tamiang Layang & 21 \\
SMPN 3 Tamiang Layang & 17 \\
SMPN 4 Tamiang Layang & 27 \\
SMPN Satu Atap 1 Dusun Timur & 16 \\
\hline
\end{tabular}

Source: Main Data of Primary and Secondary Education, Directorate General of Primary and Secondary Education, Ministry of Education and Culture 2019/2020

In this study, a random sampling or probability sampling technique was used. Based on the calculation result from the total population of 117 teachers with a 5\% level of distrust, this study's minimum sample size is 90.52 , written in Table 2, which rounded to 91 teachers.

Table 2. The calculation of SMPN population and sample

\begin{tabular}{lccc}
\hline $\begin{array}{c}\text { The calculation of SMPN population and } \\
\text { sample }\end{array}$ & $\begin{array}{c}\text { Population } \\
\text { (people) }\end{array}$ & Calculation & $\begin{array}{c}\text { Sample } \\
\text { (people) }\end{array}$ \\
\hline JK6EM | Journal of K6 Education and Management & 521 & Volume 3 | Number 4 | December | 2020
\end{tabular}




\begin{tabular}{|c|c|c|c|}
\hline SMPN 1 Tamiang Layang & 36 & $91 / 117 \times 36=28.00$ & 28 \\
\hline SMPN 2 Tamiang Layang & 21 & $91 / 117 \times 21=16.33$ & 16 \\
\hline SMPN 3 Tamiang Layang & 17 & $91 / 117 \times 17=13.22$ & 13 \\
\hline SMPN 4 Tamiang Layang & 27 & $91 / 117 \times 27=21.00$ & 21 \\
\hline SMPN Satu Atap 1 Dusun Timur & 16 & $91 / 117 \times 16=12.44$ & 13 \\
\hline 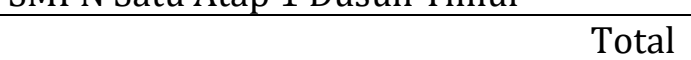 & 117 & 90.99 & 91 \\
\hline
\end{tabular}

\section{Instruments}

The general data needed in this research instrument was qualitative. A series of numbers describe the relationship between principal supervision and achievement motivation with SMPN teachers' performance in Dusun Timur Subdistrict, East Barito Regency. Analysis of the items in this research instrument examined by using the formula of product-moment as follows:

$$
r_{x y}=\frac{N \sum X Y-\left(\sum X\right)\left(\sum Y\right)}{\sqrt{\left(N \sum X^{2}-\left(\sum X\right)^{2}\left\{N \sum Y^{2}-\left(\sum Y\right)^{2}\right\}\right.}}
$$

Explanation:

$r_{x y}$ : The correlation coefficient between $\mathrm{x}$ and y (correlation coefficient of product-moment)

$\mathrm{N}$ : Total trial subjects

$\Sigma_{\mathrm{X}}{ }^{2}:$ Total x (item scores)

$\Sigma_{\mathrm{y}}$ : Total $\mathrm{x} 2$

$\Sigma_{\mathrm{y}}$ : Total y (factor scores)

$\Sigma_{\mathrm{y}}$ : Total y2

$\Sigma_{\mathrm{xy}}$ :Total times x and y (Arikunto, 2009)

Next, the price of $r_{x y}$ is consulted with an rtable of product-moment with a significant level of $5 \%$. It is said valid if the price of $r_{- \text {count }}>$ than $r_{-t a b l e}$

\section{Data collection}

This study used a questionnaire or attitude scale to collect data that was distributed to the teacher. The questionnaire was compiled based on the variables that have been determined and developed into indicators. The instrument given was in the form of questions with four alternative answers, namely;

1) Strongly agree (SS) weight 4,

2) Agree (S) weight 3 ,

3) Less agree (KS) weight 2 ,

4) Disagree (TS) weight 1.

While the scores for the questions are: $\mathrm{SS}=1, \mathrm{~S}=2, \mathrm{KS}=3, \mathrm{TS}=4$.

\section{Data analysis}

Descriptive Analysis of Variable: The application of data description was the data that has been collected is described by tabulating according to each variable. The data description was by using the help of a computer program SPSS 22 for windows so that it is obtained mean (M), standard deviation (Sd), Mode (Mo), and Median (Me) of each variable.

The inferential analysis used inferential statistics. Therefore, it is needed normality, homogeneity, and linearity tests. After the data is normally distributed and linear, it is examined for correlation and regression. Hypothesis analyses used were simple regression analysis and multiple regression analysis techniques. Path analysis, the path analysis model in this study, was a mediated path model (Figure 2). 


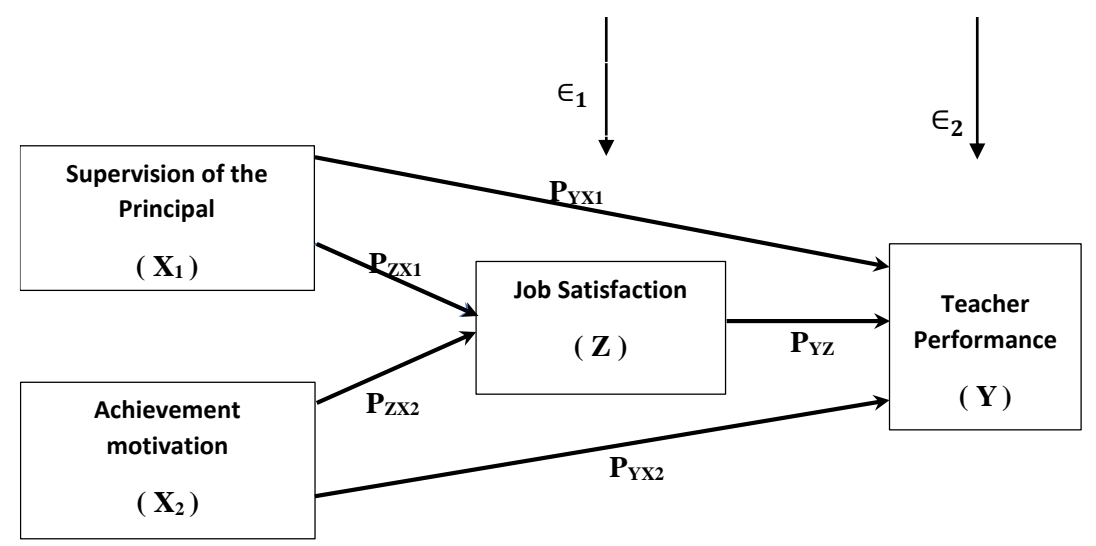

Figure 2. Path diagram

Explanation:

X1: Principal supervision

$\mathrm{X} 2$ : Achievement motivation

Y: Teacher performance

$\mathrm{Z}$ : Teacher satisfaction

$\rho$ (rho): the coefficient of each variable

$\rho z x 1$ : Path coefficient of principal supervision with job satisfaction

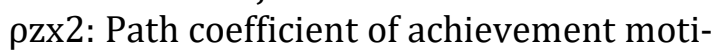
vation with job satisfaction

pyx1: Path coefficient of principal supervision on teacher performance

pyx2: Path coefficient of achievement motivation on teacher performance

$\rho z y$ : Path coefficient of teacher performance on teacher satisfaction

rx1x2: Correlation coefficient between independent variables

$\varepsilon$ (epsilon): other factors that affect the dependent variable (other than those affected which are not examined)

\section{Result and Discussion}

This study uses a descriptive correlational design and path diagrams. The data analysis process uses SPSS 22 software tool. The study results show that all statistical hypotheses were $r_{\text {-count }}>r_{\text {-table }}$, at the 5\% significance level. This means the explanation regarding:

\section{The relationship between principal supervi-} sion $\left(X_{1}\right)$ and job satisfaction ( $\left.\mathrm{z}\right)$

Based on the validity test results, it is seen that the value of $r$-count is greater than the value of $r$-table due to the result $>0,3$, so it can be understood that all statement items included in this study are valid.
Based on the reliability test, it is known that school supervision) and job satisfaction ( $\mathrm{z}$ ) has a Cronbach Alpha coefficient of 0.762 and 0.761 , respectively, which are greater than the standard Cronbach Alpha coefficient of 0.6. Thus, it can be said that the result of the reliability test for each variable is reliable.

The T-test is conducted to examine the hypothesis. The result indicates that: 0.753 and; 0.2061 in which r-count >rtable. Thus, this analysis concludes a significant correlation between School Supervision) and Job Satisfaction (Z). To determine the effect size of the independent variable (school supervision) with the dependent variable (job satisfaction), it can be seen from the value of the coefficient of determination. The result of is 0.568 . This value means that a $56.8 \%$ change in the job satisfaction variable (Z) can be explained by the School Supervision variable. Meanwhile, $43.2 \%$ is explained by other variables, including job satisfaction (Z) and other variables not examined in this study. Furthermore, the test result of simple linear regression indicates that the coefficient of the effect of to $\mathrm{Z}$ is 0.005 or $0.5 \%$, and it is obtained the equation $Y=33.639+0.421$. The regression equation above indicates a positive direction. Therefore, there is a positive effect between School Supervision and Job Satisfaction (Z). If increases by 1 point, then (Z) will increase by 0.421 points.

Based on the analysis above, it can be concluded that there is a very small positive and significant effect between and Job Satisfaction (Z). This research is supported by the research result conducted by Sarjana (2012), which also finds that principals' supervision affects 
teacher job satisfaction. Another research that also supports the result is research conducted by Hadi (2007), which also finds a similar result. That is, well-done supervision can make workers feel satisfied with the work done.

\section{The relationship between achievement moti- vation ( $\left.\mathrm{X}_{2}\right)$ and job satisfaction ( $\mathrm{z}$ )}

Based on the validity test result, it is known that the value of $r$ count is greater than the value of $r_{\text {-table }}$ since the result is $>0.3$ so it can be said that all statement items used in this study are valid.

Based on the reliability test, it is known that Achievement Motivation $\left(X_{2}\right)$ and Job Satisfaction (Z) have Cronbach Alpha coefficients of 0.760 and 0.761 consecutively greater than the standard Cronbach Alpha coefficient of 0.6. Thus, it can be said that the result of the reliability test for each variable is reliable. To test the hypothesis, it is done by using a t-test. The result is known that $\mathrm{r}_{\text {-count }}$ : 0.165 and $\mathrm{r}_{\text {-table: }}$ : 0.2061 in which $r_{\text {count }}<r_{\text {table }}$. Thus, it can be concluded that there is an insignificant correlation between Achievement Motivation $\left(X_{2}\right)$ and Job Satisfaction (Z).

To determine the effect size of the independent variable (achievement motivation) with the dependent variable (job satisfaction), it can be seen from the value of the coefficient of determination. The result of $R^{2}$ is 0.027 . This value means that a $2.7 \%$ change in the job satisfaction variable $(\mathrm{Z})$ can be explained by the achievement motivation variable (X2). Meanwhile, $97.3 \%$ is explained by other variables, including job satisfaction (Z) and other variables not examined in this study. Furthermore, the test result of simple linear regression shows that the coefficient of the effect of $\left(X_{2}\right)$ with $(\mathrm{Z})$ is 0.005 or $0.5 \%$, and it is obtained the equation $\mathrm{Y}=62.994+0.132 \mathrm{X}_{2}$. The regression equation above indicates a positive direction. Thus, there is a positive effect between $\left(X_{2}\right)$ and (Z). This means if $X_{2}$ increases by 1 point, then $(\mathrm{Z})$ will increase by 0.132 points.

Based on the analysis above, it can be concluded that there is a very small positive and insignificant effect between Achievement Motivation $\left(X_{2}\right)$ and Job Satisfaction (Z). The result contradicts the results of the previous studies, such as research conducted by Ahmadiansah (2016), Tukiyo (2015), and Juniari \& I Gede Riana (2015), which find that motivation affects job satisfaction.

\section{The relationship between school supervision $\left(X_{1}\right)$ and teacher performance $(Y)$}

Based on the result of the validity test, it is known that the value of $r$ count is greater than the value of $r$ table as a result $>0.3$, so it can be said that all statement items used in this study are valid.

Based on the reliability test, it is known that School Supervision $\left(X_{1}\right)$ and Teacher Performance $(\mathrm{Y})$ have Cronbach Alpha coefficients of 0.762 and 0.754 , respectively, which are greater than the standard Cronbach Alpha coefficient of 0.6. Thus, it can be said that the result of the reliability test for each variable is reliable. To test the hypothesis, it is done by using the t-test. The result is known that $r_{- \text {count }}$ : 0.677 and $r_{- \text {table }}: 0.2061$ in which $r_{\text {count }}>r_{\text {table }}$. Thus, it can be concluded that there is a significant correlation between School Supervision $\left(X_{1}\right)$ and teacher Performance $(\mathrm{Y})$.

To determine the effect size of the independent variable (school supervision) with the dependent variable (teacher performance), it can be seen from the value of the coefficient of determination. The result of $R^{2}$ is 0.458 . This value means that a $45.8 \%$ change in the teacher performance variable (Y) can be explained by the School Supervision variable $\left(X_{1}\right)$. Meanwhile, $54.2 \%$ is explained by other variables, including teacher performance (Y) and other variables not examined in this study. Furthermore, the test result of simple linear regression shows that the coefficient of the effect of $\left(X_{1}\right)$ with $(\mathrm{Y})$ is 0.005 or $0.5 \%$, and it is obtained the equation $Y=53.040+0.493 X_{1}$. The regression equation above shows a positive direction.Thus, there is a positive effect between $\left(X_{1}\right)$ and $(Y)$. This means if $X_{1}$ increases by 1 point, then $(Y)$ will increase by 0.493 points. The analysis above shows a very small significant and positive effect between the effect of School Supervision $\left(X_{1}\right)$ and Teacher Performance (Y). The result of this study is similar to the research conducted by Imah (2018), Rismawan (2015), Supardi (2017), and 
Lastriyani \& Herawan (2013), which find that supervision has a positive effect on teacher performance.

\section{The relationship between achievement moti- vation $\left(\mathrm{X}_{2}\right)$ and teacher performance $(Y)$}

Based on the result of the validity test, it is known that the value of $r_{\text {count }}$ is greater than the value of the ${ }^{r}$ table since the result $>0.3$, so it can be said that all statement items used in this study are valid.

Based on the reliability test, it is known that Achievement Motivation $\left(X_{2}\right)$ and Teacher Performance (Y) have Cronbach Alpha coefficients of 0.760 and 0.754 , respectively, which are greater than the standard Cronbach Alpha coefficient of 0.6. Thus, it can be said that the result of the reliability test for each variable is reliable.

To test the hypothesis, it is done by using the t-test. The result is known that $r_{- \text {count }}$ : 0.677 and $r_{-t a b l e} ; 0.2061$ in which $r_{\text {count }}>r_{\text {table }}$. Thus, it can be concluded that there is a significant correlation between Achievement Motivation $\left(X_{2}\right)$ and teacher Performance $(Y)$. To determine the effect size of the independent variable (achievement motivation) with the dependent variable (teacher performance), it can be seen from the value of the coefficient of determination. The result of $R^{2}$ is 0.049 . This value means that a $4.9 \%$ change in the teacher performance variable $(\mathrm{Y})$ can be explained by the Achievement Motivation variable $\left(X_{2}\right)$. Meanwhile, $95.1 \%$ is explained by other variables, including teacher performance $(\mathrm{Y})$ and other variables not examined in this study.

Furthermore, the test result of simple linear regression shows that the coefficient of the effect of $\left(X_{2}\right)$ with $(Y)$ is 0.005 or $0.5 \%$, and it is obtained the equation $\mathrm{Y}=79.998+0.232 \mathrm{X}_{2}$. The regression equation above indicates a positive direction. Thus, there is a positive effect between $\left(X_{2}\right)$ and $(Y)$. This means if $X_{2}$ increases by 1 point, then $(Y)$ will increase by 0.232 points.

Based on the analysis above, it can be concluded that there is a very small significant and positive effect between the effect of Achievement Motivation $\left(X_{2}\right)$ and Teacher Performance (Y). This study supports the result of previous studies conducted by Sumarni (2016) and Wibowo (2017), which find that achievement motivation positively affects teacher performance.

\section{The relationship between job satisfaction (Z) and teacher performance $(Y)$}

Based on the result of the validity test, it is known that the value of $r_{\text {count }}$ is greater than the value of ther $r_{\text {table }}$ due to the result $>0.3$, so it can be said that all statement items used in this study are valid. Based on the reliability test, it is known that Job Satisfaction (Z) and Teacher Performance ( $\mathrm{Y}$ ) have Cronbach Alpha coefficients of 0.761 and 0.754 , respectively, which are greater than the standard Cronbach Alpha coefficient of 0.6 . Thus, it can be said that the result of the reliability test for each variable is reliable.

The T-test is conducted to examine the hypothesis. The result shows that $r_{- \text {count }}: 0.872$ and $r$-table; 0.2061 in which $r_{\text {count }}>r_{\text {table }}$. Thus, the analysis above shows that the result has a significant correlation between Job Satisfaction (Z) and Teacher Performance (Y). This result is supported by Lismida \& Meilani's (2017) research, which finds that job satisfaction affects Vocational School teachers' performance positively. To determine the effect size of the independent variable (job satisfaction) with the dependent variable (teacher performance), it can be seen from the value of the coefficient of determination. The result of $R^{2}$ is 0.760 . This value means that a $76 \%$ change in the teacher performance variable (Y) can be explained by the job satisfaction variable (Z). Meanwhile, $24 \%$ is explained by other variables, including teacher performance $(\mathrm{Y})$ and other variables not examined in this study.

Furthermore, the test result of simple linear regression indicates that the coefficient of the effect of $(\mathrm{Z})$ with $(\mathrm{Y})$ is 0.005 or $0.5 \%$, and it is obtained the equation $\mathrm{Y}=16.278+1.136 \mathrm{Z}$. The regression equation above shows a positive direction. Thus, there is a positive effect between $(\mathrm{Z})$ and $(\mathrm{Y})$. If $\mathrm{Z}$ increases by 1 point, then $(\mathrm{Y})$ will increase by 1.136 points.

The relationship between school supervision $\left(X_{1}\right)$ and achievement motivation $\left(X_{2}\right)$ with job satisfaction (Z) 
Based on the validity test result, it is known that the value of $r_{\text {count }}$ is greater than the value of $r_{\text {-table }}$ since the result $>0.3$. Thus, it can be said that all statement items used in this study are valid.

Based on the reliability test, it is known that School Supervision $\left(\mathrm{X}_{1}\right)$ And Achievement Motivation $\left(\mathrm{X}_{2}\right)$ With Job Satisfaction (Z) have Cronbach Alpha coefficients of 0.762, 0.760, and 0.761 , respectively, greater than the standard Cronbach Alpha coefficient of 0.6. Thus, it can be said that the result of the reliability test for each variable is reliable. To test the hypothesis, it is done by using the t-test. The result is known that $r$-count: 0.766 and $r_{- \text {table }} 0.2061$ in which $r_{\text {count }}>r_{\text {table }}$. Thus, it can be concluded that there is a significant correlation between School Supervision $\left(\mathrm{X}_{1}\right)$ And Achievement Motivation $\left(\mathrm{X}_{2}\right)$ With Job Satisfaction $(\mathrm{Z})$.

To determine the effect size of the independent variables (school supervision, achievement motivation) with the dependent variable (job satisfaction), it can be seen from the value of the coefficient of determination. The result of $R^{2}$ is 0.587 . This value means that a $58.7 \%$ change in the Job satisfaction variable (Z) can be explained by the school supervision variable $\left(X_{1}\right)$ and the achievement motivation variable $\left(X_{2}\right)$. Meanwhile, $41.3 \%$ is explained by other variables not examined in this study.

Furthermore, the test result of simple linear regression indicates that the effective coefficient of $\mathrm{X}_{1}$ and $\mathrm{X}_{2}$ to $\mathrm{Z}$ is 0.005 or $0.5 \%$ and it is obtained the equation $\mathrm{Y}=4.469+0.418 X_{1}+$ $0.111 X_{2}$. The regression equation above indicates a positive direction. Thus, there is a positive effect between $\mathrm{X} 1$ and $\mathrm{X} 2$ to $\mathrm{Z} .\left(X_{1}\right)$ of 0.418 means if school supervision $\left(X_{1}\right)$ increases by 1 point. Job satisfaction $(\mathrm{Z})$ will increase by 1 point, and the coefficient value is very small for $\left(X_{2}\right)$ of 0.111 , which means if achievement motivation $\left(X_{2}\right)$ increases by 1 point, then job satisfaction (Z) will increase by 1 point. Based on the analysis above, it can be concluded that there is a very small significant and positive effect between the effect of School Supervision $\left(\mathrm{X}_{1}\right)$ and Achievement Motivation $\left(\mathrm{X}_{2}\right)$ on Job Satisfaction $(\mathrm{Z})$.
The relationship of school supervision $\left(X_{1}\right)$ and job satisfaction (Z) with teacher performance (Y)

Based on the validity test results, it is known that the value of $r$ count is greater than the value of $r$ table because the results $>0.3$, so it can be said that all statement items used in this study are valid.

Based on the reliability test, it is known that School Supervision ( $\mathrm{X}_{1}$ ) And Job Satisfaction (Z) With Teacher Performance (Y) have Cronbach Alpha coefficients of $0.762,0.761$, and 0.754 , respectively, greater than the standard Cronbach Alpha coefficient of 0.6. Thus, it can be said that the result of the reliability test for each variable is reliable. To test the hypothesis, it is done by using the t-test. The result is known that $r$-count: 0.872 and $r_{- \text {table }}: 0.2061$ in which $r_{\text {count }}>r_{\text {table }}$. Thus, it can be concluded that there is a significant correlation between School Supervision ( $\mathrm{X}_{1}$ ) And Job Satisfaction (Z) With Teacher Performance (Y).

To determine the effect size of the independent variables (school supervision, job satisfaction) with the dependent variable (teacher performance), it can be seen from the value of the coefficient of determination. The result of $R^{2}$ is 0.760 . This value means that a $76 \%$ change in the teacher performance variable (Y) can be explained by the school supervision variable $\left(X_{1}\right)$ and the job satisfaction variable $(Z)$. Meanwhile, $24 \%$ is explained by other variables not examined in this study.

Furthermore, the test result of simple linear regression indicates that the coefficient of the effect of $\mathrm{X}_{1}$ and $\mathrm{Z}$ to $\mathrm{Y}$ is 0.005 or $0.5 \%$, and it is obtained the equation $\mathrm{Y}=16.355+0.034 \mathrm{X}_{1}+$ $1.091 \mathrm{Z}$. The regression equation above indicates a positive direction. Thus, there is a positive effect between $\mathrm{X} 1$ and $\mathrm{Z}$ to $\mathrm{Y}$. $\left(X_{1}\right)$ of 0.034 means if school supervision $\left(X_{1}\right)$ increases by 1 point, then teacher performance $(Y)$ will increase by 1 point. The coefficient value is very small for $\mathrm{Z}$ of 1.091, which means that if job satisfaction ( $Z$ ) increases by 1 point, teacher performance $(\mathrm{Y})$ will increase by 1 point.

Based on the analysis above, it can be concluded that there is a very small significant and 
positive effect between the effect of School Supervision $\left(\mathrm{X}_{1}\right)$ and Job Satisfaction (Z) on Teacher Performance (Y).

The relationship between school supervision $\left(X_{1}\right)$ and job satisfaction $(Z)$ with teacher performance

Based on the result of the validity test, it is

Based on the validity test results, it is known that the value of $r$ count is greater than the value of $r$ table, as a result, is $>0.3$, so it can be said that all statement items used in this study are valid.

Based on the reliability test, it is known that School Supervision $\left(\mathrm{X}_{1}\right)$ And Job Satisfaction (Z) have Cronbach Alpha coefficients of 0.762 and 0.761 , respectively, which are greater than the standard Cronbach Alpha coefficient of 0.6. Thus, it can be said that the result of the reliability test for each variable is reliable. To determine the effect size of the independent variables (achievement motivation and job satisfaction) with the dependent variable (teacher performance), it can be seen from the value of the coefficient of determination. The result of $R^{2}$ is 0.766 . This value means that a $76 \%$ change in the teacher performance variable (Y) can be explained by the achievement motivation variable $\left(X_{2}\right)$ and the job satisfaction variable $(Z)$. Meanwhile, $24 \%$ is explained by other variables not examined in this study.

Furthermore, the test result of simple linear regression shows that the coefficient of the effect of $\mathrm{X}_{2}$ and $\mathrm{Z}$ to $\mathrm{Y}$ is 0.005 or $0.5 \%$, and it is obtained the equation $\mathrm{Y}=9.571+0.084 \mathrm{X}_{2}+$ $1.119 \mathrm{Z}$. The regression equation above indicates a positive direction. Thus, there is a positive effect between $\mathrm{X} 2$ and $\mathrm{Z}$ to $\mathrm{Y}$. This means $\mathrm{X}_{2}$ of 0.084 , which means if achievement motivation $\left(X_{2}\right)$ increases by 1 point, then teacher performance $(Y)$ will increase by 1 point, and the coefficient value is very small for $\left(X_{2}\right)$ of 1.119 which means if job satisfaction (Z) increases by 1 point, then teacher performance $(\mathrm{Y})$ will increase by 1 point.

Based on the analysis above, it can be concluded that there is a very small positive and significant effect between Achievement Motivation $\left(\mathrm{X}_{2}\right)$ and Job Satisfaction $(\mathrm{Z})$ on Teacher Performance $(\mathrm{Y})$. Path Diagrams and their shape are determined by theoretical propositions derived from a certain frame of thinking, which can be seen as follows.

This study uses two sub-structural equations, namely.

a. Sub-Structure 1 School Supervision (X1) And Achievement Motivation (X2) With Job Satisfaction (Z) of SMPN In Dusun Timur Subdistrict, East Barito Regency.

$\mathrm{Z}=\mathrm{P}_{\mathrm{ZX} 1} \mathrm{X}_{1}+\mathrm{P}_{\mathrm{ZX} 2} \mathrm{X}_{2}+\epsilon_{1}$

Simultaneously, principal supervision and achievement motivation have positive and significant effects on job satisfaction. The simultaneous effect size, R Square of 0.587 , or rounded to $58.7 \%$, contributes to principal supervision and motivation variables on job satisfaction. Meanwhile, the remaining 41.3\% is influenced by other factors outside the model. The simultaneous (overall) model occurs $\mathrm{X}_{1}, \mathrm{X}_{2}$, with $\mathrm{Z}$ significantly. However, individually the contribution of $\mathrm{X}_{2}$, with $\mathrm{Z}$ stated as significant, and the contribution of $\mathrm{X}_{1}$, with $\mathrm{Z}$, stated as significant on job satisfaction (z). This can be seen below.

Path coefficient:

1) $\mathrm{P}_{\mathrm{zx} 1}=0.748$, since the $\mathrm{p}$-value $=0.000$ smaller than $\alpha=0.05$, this path coefficient is significant

2) $\mathrm{P}_{\mathrm{zx} 2}=0.138$, since the $\mathrm{p}$-value $=0.047$ smaller than $\alpha=0.05$, this path coefficient is significant

For empirical causal effect occurs in $\mathrm{X}_{1}, \mathrm{X}_{2}$ with $\mathrm{Z}$ can be illustrated by sub-structural equation $1 \mathrm{Z}=0.748 \mathrm{X}_{1}+0.138 \mathrm{X}_{2} \in_{1}$. Partially, principal supervision $X_{1}$ has a positive and significant effect on job satisfaction (z). The partial and direct effect size of principal supervision $\mathrm{X}_{1}$ on job satisfaction (z) is 0.748 or rounded to $74.8 \%$. Therefore, principal supervision's level of job satisfaction is $74.8 \%$, while other factors outside the model explain the remaining $25.2 \%$.

Partially, Achievement Motivation supervision $\left(\mathrm{X}_{2}\right)$ has a positive and significant effect on job satisfaction $(\mathrm{z})$. The partial and direct effect size of Achievement Motivation $\left(\mathrm{X}_{2}\right)$ on job satisfaction $(\mathrm{z})$ is 0.138 or rounded to 13.8 
$\%$. Thus, the level of job satisfaction influenced by principal supervision is $13.8 \%$, while other factors outside the model explain the remaining $86.2 \%$.

- Sub-Structure 2 School Supervision $\left(\mathrm{X}_{1}\right)$, Achievement Motivation $\left(\mathrm{X}_{2}\right)$, Job Satisfaction (Z) to Teacher Performance (Y) of SMPN In Dusun Timur Subdistrict, East Barito Regency.

$\mathrm{Y}=\mathrm{P}_{\mathrm{YX} 1} \mathrm{X}_{1}+\mathrm{P}_{\mathrm{YX} 2} \mathrm{X}_{2}+\mathrm{P}_{\mathrm{YZZ}} \mathrm{Z}+\epsilon_{2} \cdots$

Simultaneously, School Supervision $\left(\mathrm{X}_{1}\right)$ Achievement Motivation $\left(\mathrm{X}_{2}\right)$ and Job Satisfaction (Z) have positive and significant effects on teacher performance. The simultaneous effect size, R Square of 0.768 , or rounded to $76.8 \%$, contributes to the principal supervision and motivation variables to job satisfaction. Meanwhile, the remaining $23.2 \%$ is influenced by other factors outside the model.

This simultaneous (overall) model occurs $\mathrm{X}_{1}, \mathrm{X}_{2}, \mathrm{Z}$ with $\mathrm{Y}$ significantly. However, individually the contribution of $\mathrm{X}_{1}$, with $\mathrm{Y}$ stated as insignificant, the contribution of $\mathrm{X}_{2}$, with $\mathrm{Y}$ stated as insignificant, and the contribution of $\mathrm{Z}$ with $\mathrm{Y}$ stated as significant to job satisfaction (z). This can be seen below.

Path Coefficient:

$\mathrm{Y}=\mathrm{P}_{\mathrm{YX} 1} \mathrm{X}_{1}+\mathrm{P}_{\mathrm{YX} 2} \mathrm{X}_{2}+\mathrm{P}_{\mathrm{YZ}} \mathrm{Z}+\epsilon_{2}$

1) $\mathrm{P}_{\mathrm{YX} 1}=0.064$, since the $\mathrm{p}$ value $=0.423$ greater than $\alpha=0.05$, this path coefficient is insignificant

2) $\mathrm{P}_{\mathrm{YX} 2}=0.086$, since the $\mathrm{p}$-value $=0.108$ greater than $\alpha=0.05$, this path coefficient is insignificant

3) $\mathrm{P}_{\mathrm{YZ}}=0.809$, since the $\mathrm{p}$-value $=0.000$ smaller than $\alpha=0.05$, this path coefficient is significant

For empirical causal effect to occur $\mathrm{X}_{1}, \mathrm{X}_{2}, \mathrm{Z}$ with $\mathrm{Y}$ can be illustrated by sub structural equation $1 \mathrm{Y}=0.064 \mathrm{X}_{1}+0.086 \mathrm{X}_{2}+0.809 \mathrm{Z}+\epsilon_{2}$.

Partially, principal supervision $X_{1}$ has a positive and significant effect on teacher performance (Y). The partial and direct size of principal supervision $\mathrm{X}_{1}$ on teacher performance (Y). Thus, the level of teacher performance $(\mathrm{Y})$ is influenced by principal supervision by $6.4 \%$, while other factors outside the model explain the remaining 93.6\%.

Partially, Achievement Motivation ( $\left.\mathrm{X}_{2}\right)$ has a positive and significant effect on teacher performance (Y). The partial and direct effect size of Achievement Motivation $\left(\mathrm{X}_{2}\right)$ on teacher performance $(\mathrm{Y})$ is 0.086 or rounded to $8.6 \%$. Thus, the level of teacher performance (Y) affected by Achievement Motivation is $8.6 \%$, while other factors outside the model explain the remaining $91.4 \%$.

Partially, Job Satisfaction (Z). has a positive and significant effect on teacher performance (Y). The partial and direct effect size of Job Satisfaction $(\mathrm{Z})$ on teacher performance $(\mathrm{Y})$ is 0.086 or rounded to $8.6 \%$. Thus, the level of teacher performance $(\mathrm{Y})$ affected by Job Satisfaction $(\mathrm{Z})$ is $8.6 \%$, while the remaining $91.4 \%$ is explained by other factors outside the model of Path Diagram Interpretation.

The direct and indirect causal effects can be described as follows:

1) The Effect of $X_{1}$ to $Y$

- The direct effect of $\mathrm{X}_{1}$ variable on $\mathrm{Y}$ is 0.064

- The indirect effect of $X_{1}$ variable on $Y$ (through Z) is 0.605

- The Total effect of $X_{1}$ variable on $Y$ (through $\mathrm{Z}$ ) is 0.669

2) The Effect of $X_{2}$ to $Y$

- The direct effect of $\mathrm{X}_{2}$ variable on $\mathrm{Y}$ is 0.086

- The indirect effect of $X_{2}$ variable on $Y$ (through Z) is 0.111

- The Total effect of $\mathrm{X}_{2}$ variable on $\mathrm{Y}$ (through Z) is 0.197

3) The Effect of $Z$ to $Y$

- The direct effect of $\mathrm{Z}$ variable on $\mathrm{Y}$ is 0.809

\section{Conclusion and Recommendation}

Based on the results of the research and discussion, it can be concluded the following matters.

1. There is a very small positive and significant effect between School Supervision $\left(X_{1}\right)$ and Job Satisfaction (Z). 
2. There is a very small positive and insignificant effect between Achievement Motivation $\left(X_{2}\right)$ and Job Satisfaction (Z).

3. There is a very small positive and significant effect between School Supervision $\left(X_{1}\right)$ and teacher Performance $(Y)$.

4. There is a very small positive and significant effect between achievement motivation $\left(X_{2}\right)$ and teacher Performance $(\mathrm{Y})$.

5. There is a very small positive and significant effect between Job Satisfaction (Z) and Teacher Performance (Y).

6. There is a very small positive and significant effect between the effect of School Supervision $\left(X_{1}\right)$ and Achievement Motivation $\left(\mathrm{X}_{2}\right)$ on Job Satisfaction $(\mathrm{Z})$.

7. There is a very small significant and positive effect between the effect of School Supervision $\left(\mathrm{X}_{1}\right)$ and Job Satisfaction $(\mathrm{Z})$ on Teacher Performance (Y).

8. There is a very small significant and positive effect between achievement motivation $\left(\mathrm{X}_{2}\right)$ and Job Satisfaction (Z).

Based on the research results above, the authors propose the following suggestions:

1. To the principals of SMPN in Dusun Timur Subdistrict, East Barito Regency suggested that:

- Principals can plan for supervision well, carry out supervision well, and follow up on supervision results effectively. These will encourage the increase of teacher job satisfaction in carrying out their duties in school.

- The principal supervision activity should be conducted periodically minimal every semester once and more planned according to the existing procedures. This is important to improve teacher perception regarding principal supervision.

- Shool should conduct workshops to improve teacher performance in managing the teaching and learning process, student learning evaluation, and mastering educational cornerstone.

- Principals should encourage teachers to feel satisfied when they have successfully passed risky work. Schools also need to reward teachers who have high achievement motivation and teaching performance.

2. To the teachers of SMPN in Dusun Timur Subdistrict, East Barito district.

- Teachers' perceptions regarding principal supervision need to be improved. This can be done by changing the teacher's perspective on the old meaning of supervision, namely that supervision is carried out to find teacher mistakes. Still, supervision here can be interpreted as a control for teachers in teaching and learning activities. This is evidenced by supervision activity as a coaching process and rewards and punishments as a follow-up to the supervision activity.

- It needs to improve motivation to get more achievement in all fields. The way to improve teacher achievement motivation can be by providing incentives for those who get an achievement and giving hope that teachers have high responsibility and competitiveness.

- It needs to feel satisfied if we have successfully passed a risky job to continue to be motivated to achieve our performance.

- It is necessary to improve teacher teaching performance so that the learning process's objectives can be achieved.

3. For researchers

- It is necessary to conduct further research on teacher perceptions regarding principal supervision, achievement motivation, and job satisfaction with broader teacher performance.

- Research needs to be conducted with a longer time and more respondents to obtain more objective data.

- It needs other variables that can contribute more to the variable of teacher teaching performance. 
- Researchers can use this study's results with similar themes and further research variables with different themes for SMPN teachers in the Dusun Timur Subdistrict, East Barito district.

\section{Acknowledgment}

Author say thanks to Master Program of Education Management, Universitas Lambung Mangkurat for supporting this research.

\section{References}

Ahmadiansah, R. (2016). The influence of work motivation and job satisfaction on teacher performance of SMK muhammadiyah salatiga. Interdisciplinary Journal of Communication, 1(2), 223-236.

Arikunto, S. (2009). Research methodology: A practical approach. Jakarta: Rineka Cipta.

Bakar, R. (2018). The influence of professional teachers on Padang vocational school students' achievement. Kasetsart Journal of Social Sciences, 39(1), 67-72. doi:https://doi.org/10.1016/j.kjss.2017.12.017

Behroozi, M., Fadaiya, B., \& S. K. (2014). the study of secondary school principals' performance status according to fiedler theory in Bushehr: Iran's perspective. Procedia - Social and Behavioral Sciences, 143, 394-398. doi:10.1016/j.sbspro.2014.07.501

Bentea, C.-C., \& Anghelache, V. (2012). Teachers' motivation and satisfaction for professional activity. Procedia - Social and Behavioral Sciences, 33, 563-567. doi:https://doi.org/10.1016/j.sbspro.2012.01.184

Blaskova, M., Blasko, R., Figurska, I., \& A. S. (2015). Motivation and development of the university teachers' motivational competence. Procedia - Social and Behavioral Sciences, 182, 116 - 126. doi: 10.1016/j.sbspro.2015.04.746

Bush, A., \& Grotjohann, N. (2020). Collaboration in teacher education: A cross-sectional study on future teachers' attitudes towards collaboration, their intentions to collaborate and their performance of collaboration. Teaching and Teacher Education, 88, 102968. doi:https://doi.org/10.1016/j.tate.2019.102968

Claudia, V. (2015). The role of motivation in the development of school teachers 'career. Procedia - Social and Behavioral Sciences, 180 , 1109-1115. doi:10.1016/j.sbspro.2015.02.220

Fraenkel, J. R., Wallen, N. E., \& Hyun, H. H. (2012). How to design and evaluate research in education (8th ed.). New York: McGraw Hill.

Gherasim, L. R., Maireana, C., \& Butnaru, S. (2012). Prediction of school performance: the role of motivational orientation and classroom environment. Procedia - Social and Behavioral Sciences, 46, 3931-3935. doi:https://doi.org/10.1016/j.sbspro.2012.06.174

Hadi, S. (2007). The effect of supervision on work satisfaction of accountant beginner. JAAI, 11(2), 187-192.

Hubackova, S. (2015). Modern methods of University student's activation. Procedia - Social and Behavioral Sciences, 171, 241 - 245. doi:10.1016/j.sbspro.2015.01.116

Imah, C. (2018). The effect of principal supervision on public elementary school teachers' performance of air kumbang sub-district, banyuasin district. Jurnal Administrasi Pendidikan, 1(2), 65-77.

Juniari, N. k., \& I Gede Riana, M. S. (2015). The influence of motivation on job satisfaction and performance of civil servants (pns) of tourism high school of nusa dua bali. $E$ Jurnal Ekonomi dan Bisnis Universitas Udayana, 4(11), 823840.

Kandemira, M. A., \& Gür, H. (2009). What motivates mathematics teachers? Procedia Social and Behavioral Sciences, 1, 969974. doi:10.1016/j.sbspro.2009.01.172

Kelimeda, Hairudinor, Ridwan, M. N., \& Dalle, J. (2018). the effect of motivation, job satisfaction and job disciplinetoward employee performance of PT. Buma Perindahindo at Lng Tangguh Site, Teluk Bintuni Regency, West Papua, Indonesia. European Journal of Human Resource Management $\quad$ Studies, 2(1), 49-73. doi:10.5281/zenodo.204045

Lastriyani, I., \& Herawan, E. (2013). The effect of principal supervision and compensation on teacher teaching performance. Jurnal Administrasi Pendidikan, 17(1), 96106.

Lile, R., \& Kelemen, G. (2014). Teaching/learning/assessment based on interactive learning methods. Procedia - Social and Behavioral Sciences, 163, 120-124. doi:https://doi.org/10.1016/j.sbspro.2014.12.296

Lismeida, R. A., \& Meilani, R. I. (2017). Teacher job satisfaction and performance: a study of certified vocational school teachers in Indonesia. Jurnal Pendidikan Manajemen Perkantoran, 2(1), 57-65.

Liu, S.-H., \& Tsai, H.-C. (2017). Teachers' experiences of collaborating in school teaching teams. Asian Social Science, 13(2), 159-168. doi:http://dx.doi.org/10.5539/ass.v13n2p159

Lourmpas, S., \& Dakopoulou, A. (2014). educational leaders and teachers' motivation for engagement in innovative programmes. the case of greece. Procedia - Social and Behavioral Sciences, 116, 3359-3364. doi:https://doi.org/10.1016/j.sbspro.2014.01.764

Luskova, M., \& Hudakova, M. (206). Approaches to teachers' performance assessment for enhancing quality of 
education at universities. Procedia - Social and Behavioral Sciences, 106, 476-484

Poernamawijaya, L. W., Sulaiman, S., Suriansyah, A., \& Dalle, J. (2018). Contribution to supervision of supervisor, principals motivation, and kindergarten teacher performance improves the kindergarten quality in West Banjarmasin, Indonesia. European Journal of Alternative Education $\quad$ Studies, $\quad 3(2), \quad 129-146$ doi:10.5281/zenodo.2261031

Rismawan, E. (2015). The effect of principal supervision and teacher achievement motivation on teacher teaching performance. Jurnal Administrasi Pendidikan, 22(1), 114132.

Sarjana, S. (2012). The influence of supervision and organizational climare on job satisfaction. Jurnal Kependidikan, 42(2), 173-186. doi:https://doi.org/10.21831/jk.v42i2.1951

Schratz, M., \& Schle, W. (2014). Educational leaders as change agents in system development: The Austrian Leadership Academy. Journal of Contemporary Educational Studies, 4, 13-29.

Sumarni. (2016). Contribution of achievement motivation and principal leadership to public high school teachers' performance in koto tangah sub-district padang city. ournal of Economic and Economic Education, 5(1), 68- 74. doi:http://dx.doi.org/10.22202/economica.v5i1.307

Supardi. (2017). The effect of the head of madrasah's supervision in improving teacher performance. Studia Didaktika: Jurnal Ilmiah Bidang Pendidikan, 11(1), 63-70.

Taştan, S. B., Davoudi, S. M., Masalimova, A. R., Bersanov, A. S. Kurbanov, R. A., Boiarchuk, A. V., \& Pavlushin, A. A. (2018).
The impacts of teacher's efficacy and motivation on student's academic achievement in science education among secondary and high school students. EURASIA Journal of Mathematics, Science and Technology Education, $14(6)$, 2353-2366. doi:https://doi.org/10.29333/ejmste/89579

Tukiyo. (2015). Motivation and job satisfaction of primary school teachers in Klaten Regency. Seminar Nasional Pendidikan UNS \& ISPI (pp. 158-168). Surakarta: Universitas Sebelas Maret Surakarta.

Vangrieken, K., Dochy, F., Raes, E., \& Kyndt, E. (2015). Teacher collaboration: A systematic review. Educational Research Review, 15, 17-40. doi:http://dx.doi.org/10.1016/j.edurev.2015.04.002

Veloo, A., Komuji, M. M., \& Khalid, R. (2013). The effects of clinical supervision on the teaching performance of secondary school teachers. Procedia-Social and Behavioral Sciences, 93, 35-39. doi: 10.1016/j.sbspro.2013.09.148

Walker, T. L., \& Vogt, J. F. (1987). The school administrator as change agent: Skills for the future. NASSP Bulletin, 71(502), 41-48. doi:https://doi.org/10.1177/019263658707150207

Wibowo, D. H. (2017). Achievement motivation in relation to teacher performance. Scholaria, 5(3), 65-74.

Yunus, M. M., Safuraa, W., Osman, W., \& Ishak, N. M. (2011). Teacher-student relationship factor affecting motivation and academic achievement in ESL classroom. Procedia Social and Behavioral Sciences, 15, 2637-2641. doi:https://doi.org/10.1016/j.sbspro.2011.04.161 